\title{
Digital 2D Animation for Educational Visualization in Secondary School: A Development Courseware of Bintang Hati PT3 Novel
}

\author{
Mu'azah Md. Aziz, Ainul Maulid Ahmad, Gani Ibrahim Musa, Wan Mahani Abdullah, \\ Mohamad Izril Ishak, Mohd. Aswad Amat Mushim
}

\begin{abstract}
Multimedia technology has opened up new opportunities and exploration to be exploited in learning environment. This technology has the ability to integrate, combine, and deliver various media such as text, graphic, audio, video, animation and interactivity which can help make teaching and learning process more effective and rewarding. However, a multimedia courseware development high-quality and cost-effective is a major challenge that needs to be addressed and focused if we want to integrate the multimedia application a real success. This study presents development of a multimedia courseware using $2 D$ animation for PT3 students in secondary school in assisting them to learn about the Bintang Hati novel using visualization technique. The development courseware is an alternative of the conventional learning method using chalk and talk. Integrating the multimedia elements in learning method will make the learning environment more interesting and presentable. ADDIE model has been used as guidelines in developing the courseware. Each phases and activities of the model are discussed in detail based on the development process involved. The methodology for courseware quality assurance and its relationship with the development process model have been presented. By using the observation, questionnaire, and interview method in data collection, the result of the successful courseware development is also presented.
\end{abstract}

Index Terms: Multimedia courseware, 2D animation, PT3 students, ADDIE model.

\section{INTRODUCTION}

In order to transform the conventional method of learning

Revised Manuscript Received on September 22, 2019.

Mu'azah Md. Aziz, Kulliyyah Muamalat and Management Sciences, Universiti Islam Antarabangsa Sultan Abdul Halim Mu'adzam Shah, 09300 Kuala Ketil, Kedah, 09300, Malaysia.muazah@unishams.edu.my

Ainul Maulid Ahmad, Kulliyyah Muamalat and Management Sciences, Universiti Islam Antarabangsa Sultan Abdul Halim Mu'adzam Shah, 09300 Kuala Ketil, Kedah, 09300, Malaysia

Wan Mahani Abdullah, Kulliyyah Muamalat and Management Sciences, Universiti Islam Antarabangsa Sultan Abdul Halim Mu’adzam Shah, 09300 Kuala Ketil, Kedah, 09300, Malaysia

Mohamad Izril Ishak, Kulliyyah Muamalat and Management Sciences, Universiti Islam Antarabangsa Sultan Abdul Halim Mu'adzam Shah, 09300 Kuala Ketil, Kedah, 09300, Malaysia

Gani Ibrahim Musa, Economics Department, Isa Kaita College of Education Dutsinma, 5007 Katsina State Nigeria

Mohd. Aswad Amat Mushim, Continental Automotive Components Malaysia Sdn. Bhd., Prai Industrial Estate, 13600 Perai, Pulau Pinang, Malaysia. in secondary school into integrated technology, the teaching and learning process needs to change in tandem with the rapid growth of technology. Technology and learning in the modern times have succeeded in growing together with a variety of techniques and tools that can provide a more engaging and effective learning environment. The exploration of global knowledge and advanced skills among students requires a change to learning strategies and techniques. The continuous development of computer network and multimedia technologies has increased along with the demand from people for animation design. A course offers on $2 \mathrm{D}$ animation production have begun in various educational institution. However, this course strong practicality requires students to not only master the basic theoretical knowledge of animation production. Nevertheless, by simply relying only to experimental or traditional verification operations experiments, one cannot effectively teach animation design [1]. A science related course teaching materials containing concrete evidence, specifically for multimedia animations or virtual objects, have significant effects on student learning based on the proposed from prior studies [2].

\section{A. Current Learning Approach}

In the current learning approach, the specific problems occur have been identified from the interview session with the Subject Matter Expert. Currently, the method of learning and learning materials form are still in the traditional content of printed books with passive prints combined with illustrations and more text. Thus, the current learning method needs learner trying to understand the content based on the printed books and also needs the learner to imagine the situation happened based on the books content. Besides, to follow up the knowledge learnt in the learning activities to follow up the knowledge learnt are easily get misplaced sheets of paper and needs to be carefully handled. In addition, there is lack of software for educational to teach Bahasa Melayu syllables in the market. Other than that, there are most of the educational courseware available in market that has more elements of entertainment instead of academic value for teaching and learning. Hence, learner usually enjoy playing the games from the software but there is lesser retention of what they have learnt.

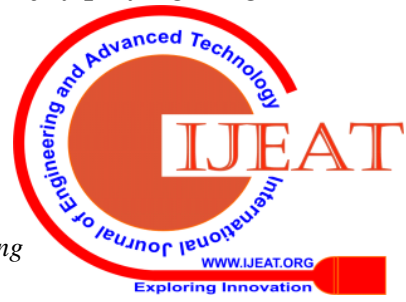


Moreover, because of lack interested of learning using current method educational system is geared primarily towards trying to teach the secondary school learner nowadays to integrate the technology in their learning method. Emphasis of this study is placed on develop the visualization content materials which can help students to remember the knowledge learnt for long term. According to John King, a U.S. Secretary of Education, "one of the most important aspects of technology in education is its ability to level the field of opportunity for students."

\section{B. Current Teaching Approaches}

Researches are constantly identifying the effective methods of teaching and learning. However, the appropriate teaching approach to be selected is not a "one-size-fits-all" situation but rather is based on a more evaluation and detailed which involves a thorough assessment of the needs in education system. In school, teachers normally telling the stories because it is easily influence people's lives because they can carry the memories of the past to them, then to the future generation. According to [3], the key roles in human thinking and communication have been playing by them. The impact of stories in language and skill's literacy is well established in the literature [4-10]. "Stories...can help learners appreciate and respect the culture and the values of various groups. These stories foster the transformative powers of education" [5].

In Malaysia, since 2003, the most important tools in assisting teachers in classrooms is multimedia courseware when teachers need to teach subjects Science and Mathematics in English [11]. The multimedia courseware made the teachers believed that it helps students to understand better in Science and Mathematics subjects and at the same time it helped the teachers delivering their lessons in English better. According to [11], to overcome the learning problems occur among students and teaching problems occur among teachers in the teaching and learning process, these multimedia courseware is useful to implement.

Visuality become more prominent over time with the emerging technologies and needs [12]. The most important benefits of using animations in teaching individuals with special needs are the visuality, moving objects, and making visual objects more narrative. Besides, the use of animation in special education has recently come into prominence in considering the prevalent and efficient use of animation in education and technology in special education based on its advantages. For example, [13] were investigated the potential benefit of animated instructional tools for students with dyslexia learning in higher education and it is showed that the appropriate animated instructional materials facilitate learning more when compared to the static materials.

\section{LITERATURE}

\section{A. IT and Teaching}

According to [14], the existence of IT plays an important role in reshaping the curriculum system and pedagogy of Science's subject [15]. The practical and theoretical aspects of Science teaching and learning both can be enhanced by IT. [14] have proposed a range of various IT tools, for use in activities Science in school which include computer projection technology, simulation process using multimedia software in publishing and performing virtual presentation experiments, digital recording equipment, computer-controlled microscope and also tools for data logging systems, graphing tools, data capture, and modeling environments. There is existing a growing importance for IT within the school's curriculum. Teachers need to support teaching techniques at every level and level of learning by applying computer and related technologies using computers and related technologies. Aiming to improve knowledge, understanding, and skills in IT use, teachers need to provide appropriate technology facilities in student life.

From a variety of sources and in many different ways, IT tools enable pupils to access, share, analyze, and present information gained. Besides that, the use of IT provides opportunities for pupils to work both independently and collaboratively. Therefore, teachers have indicated that they preferred educational software that allows invites transference of skills, stimulate thinking, and choices [16] As such, it shows that educational software is preferred by teachers, which enables stimulation of thinking, transferable skills and making choices. From that continuity, the role of IT in teaching courses is to enhance classroom interaction as a means of sharing knowledge within the curriculum. In addition, it not only helps students improve their learning experience but also helps students to develop important skills indirectly in the classroom. In addition, it enhances teamwork and creates social unity and value. Various studies have been conducted on the effectiveness of technology as an educational tool.

Generally, the use of IT in education are as the following functions: a) IT as objects. It refers to learning about IT. In a specific course it is mostly organized. It is depending on the type of education and the level of the students for what is being learned. Besides that, for the use of IT in education, future occupation, and social life are coming from education that will prepares students towards it b) IT as an 'assisting tool', IT also is used as a tool, for example while making assignments, communicating and conducting research, documentation and collecting data. Typically, from the subject matter IT is used independently which is; c) IT will be a medium for process in teaching and learning. The medium through which teachers can teach and learners can learn is refers to IT as a tool for teaching and learning itself It can appear in many different dorms, such as in simulation and educational networks drill and practice exercise, and d) IT also as a tool for organization and management process in schools.

\section{B. Multimedia and Teaching}

A lot of researches have been done to study on how knowledge can be shared and effectiveness of using multimedia. The learning of multimedia technology enhances by its ability to combine sound, diagrams, pictures, image, texts, graphics, and interactivity with appropriate animation and simulation that can encourage learning through all senses and motivation and stimulate 
learners mind. In learning Physics, the use of visualization and simulation tools can help students to reason qualitatively about processes of physical, recognize patterns, and envision dynamic models. These curricular approaches can improve success for all learners' types and may enhance the performance of the students differentially. The range and quality of materials has proved for the courseware to be the strongest feature. Therefore, to prepare for classroom discussion and tutorial, teachers most often use the courseware to support the process of teaching, while students may use it independently or in computer lab sessions [11].

The courseware is normally developed with flexible set of "core resources" that could be incorporated into existing teaching programs. According [17], the development of hardware and computer-based software package produced on a large scale also means as a courseware and its allow the use and learning individually. To makes the tutorials as flexible learning tools, it will

use the enriched-lecture multimedia format, using Web browsers and HTML. Students may respond to the information differently. Thus, to teach the subject matter of a lesson, with the advantages that teachers have, teachers can often apply different formats and methods to the teaching process. This is why for conveying information, the use of a combination of lecture delivery methods is commonly used by teachers, hands-on laboratory, and text. With the advent of the Internet and all kinds of formats, there are new and exciting ways for teachers today to present information through the World Wide Web. The integration of animations, sounds, and pictures into lessons allowed through the Internet, extending their functionality and ability to present materials that enable them to encourage student interaction with the subject. Besides that, animations and pictures help bring to life scientific principles, and multimedia can help students become more engaged in the learning process: they will be able to watch experiments in action. Among the advantages of using multimedia is it enable on effectively and quickly convey information to all students and ensuring that there is interest in their learning process. In this study, development courseware uses all the elements of multimedia to enhance student attractiveness and interest to focus on the content displayed.

\section{The Use of Animation}

A graphic representation of drawings is called animation which is to show movement within those drawings. According to [18], animation is a series of drawings that are intertwined and slightly altered between individual frames, making it appear that the movements in the painting are smooth as they are replayed in rapid succession (24 frames per second). In a system of hypermedia, animations can be categorized in the $2 \mathrm{D}, 3 \mathrm{D}$, combination of $2 \mathrm{D}$ and $3 \mathrm{D}$, and metamorphosis [19]. Besides that, they appear to be moving and real, which can place emphasis on performance to engage the learner and attract users' attention. According to [19], as the objects, animations may have the similar ways of visualization. Visualization can be seen as the graphical presentation of information with the purpose of providing the viewer with information contents for qualitative understanding [20]. To have good visualization it must be effective, accurate, efficient, aesthetics, and adaptable. In order to design the effective visualization, it is necessary to study what the learner knows especially in the education's context. Thus, to provide students with the same or better quality of experience as they use with traditional teaching methods, the environments of multimedia learning must be shown to be educationally effective [21]. Therefore, with best such system will be able to improve and enhance the quality of student learning.

\section{ADDIE Model Framework}

This study was focused on the process of how to design and develop a 2D animation courseware application for Bintang Hati novel in Bahasa Melayu course by following the ADDIE theory. To produce an effective visualization application, all models of visualization design require the following phases which are: analysis, design, development, implementation, and evaluation. These visualization design phases are summarized by the acronym ADDIE, and hence it is now considered a separate model. The ADDIE model in Figure 2.1 provides a designing and developing a learning experience's systematic approach. ADDIE is a model of instructional design, which is valid for any kind of education and even though ADDIE comprises the components of all other design models and it is a relatively simple model [22]. The outcome of each ADDIE phase will informs the subsequent phase. The most popular model used for designing instruction is ADDIE model. It is providing a simple structure and easy to follow. The ADDIE model can use for educators with different instructional design experience to guide the development of their instructions. The use of rapid prototyping is the one commonly accepted improvement to this model. This is the idea of formative feedback or receiving continual while instructional materials are being made. By catching problems while they are still easy to fix, this model is attempts to save time and money.

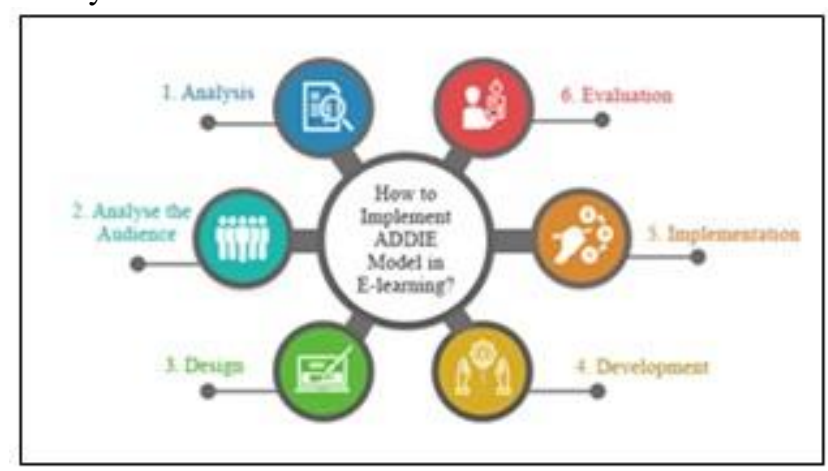

Fig 2.1. ADDIE Model (Arjun Sanal, 2018)

\section{E. Visualization in Education}

Nowadays, in environments of social media, generally the visualization's term means the process that involves of data mapping using encoding techniques of the data to maximize the human understanding. Although, before the digital technologies became commonplace, in higher education was widely used 
visualization as a learning method [23]. Besides that, according to [24], he mentioned the visual content has appeared in instructional manuals, textbooks, web interface extensions for generations, and classroom presentation. In addition, [25] says the visualization is a skill that should be taught. In the teaching of visualization, the major difficulty is that there is no single methodology, syntax, or grammar in visualization education, unlike in writing or statistics.

[26] had showed that in many ways users can visualize data, such as from simple bar charts to more complex scatterplots which is based on user experience, but to make a curriculum for teaching visualization was not suggested by them. Adding to the confusion, the student assessment in visualization education, there is no single comprehensive resource in the subject. [27] says to express information, teachers frequently use visualization, but on how to express the ideas through visualization from student that rarely receive instruction by themselves. In fact, the researcher found no studies that examine visualization as an alternative learning method in visualize the novel that used by school in Malaysia in their curriculum. Thus, this study was focused on visualization in learning and to be an alternative method for secondary school's student especially improves and increase their understanding about the novel chosen for this courseware development.

\section{Courseware Development}

This project is an application that will help the students visualize Bintang Hati novel's content as a textbook for Bahasa Melayu for students who will sit for PT3 examination in Form 3. The purpose of this courseware is to enhance students' understanding of novel content using multimedia elements. This project will start from reading the textbook's content, scratch the storyboard, design the courseware using Adobe Flash CS6 software as a main platform, and insert the suitable of multimedia elements. The project framework of the courseware development is illustrated as in the Figure 3.1.

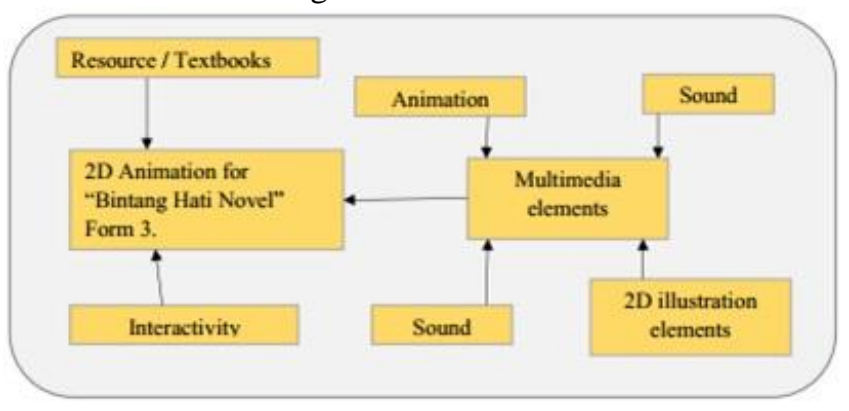

Fig 3.1. Project Framework

\section{A. Flow Chart of the Development Courseware}

In developing the courseware, the developer must have the flow chart to organize the structure of the content for make it well navigate to the right page. Every page must have proper interface with the title and content. It will make user to get the information easily without any difficulties. Thus, button is playing the main role in navigating the pages. The developer must put the correct button as a navigator to link to the other pages. In this courseware, it contains of six pages which are Digital 2D Animation
Splash Screen, Digital 2D Animation Main Menu, Digital 2D Animation Choose Story, Digital 2D Animation Story, Digital 2D Animation Synopsis, and Digital 2D Animation Other Information Page. The flow chart diagram of this development courseware is shown in the Figure 3.2.

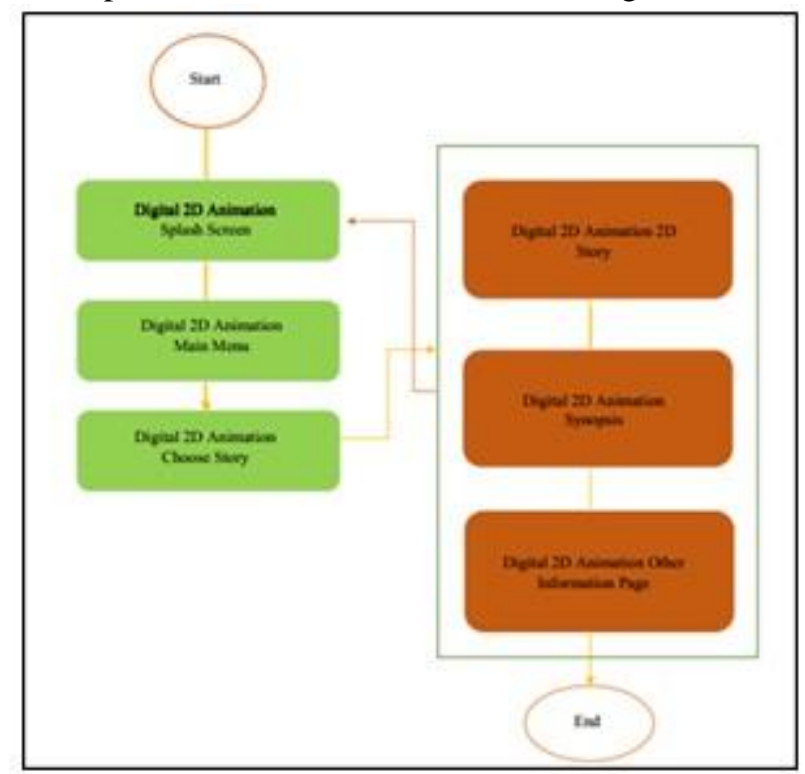

Fig 3.2. Flow Chart of the Development Courseware

\section{B. Navigation Structure}

Figure 3.3 shows the application courseware navigation structure of Digital 2D Animation for Educational Visualization, which is the movement flow of the courseware application. This navigation is referring to the element of interactivity between user and application which is the interesting element in any application technology. According to [28], e-learning systems that are perceived as interactive tend to provide a freedom and greater perceived control, and are envisaged as more enjoyable and attractive. Besides, this is also due to the higher controllability of interactive systems and the timely and understandable feedback, which may help individuals to remain focused on the task at hand [29].

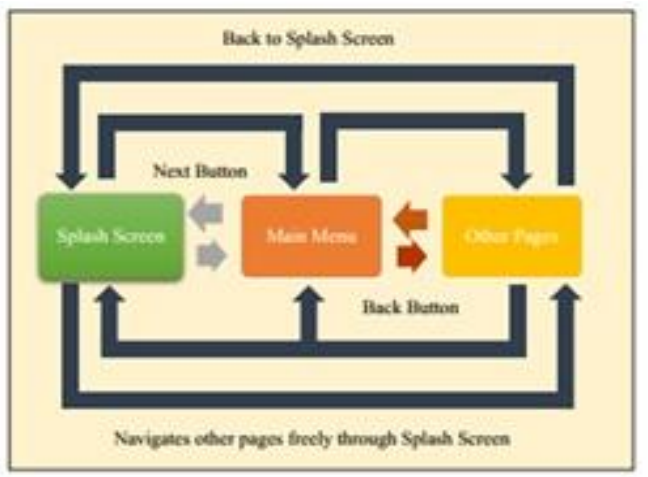

Fig 3.3. Courseware Navigation Structure

\section{Development Design of the Courseware}

The interface design as in following figures were designed using all the multimedia elements, there are graphic, animation, audio, video, text, and interactivity. The figures show the summary of two topics of the Bintang Hati novel and provided the clickable buttons to be linkable to other pages. 
1) Interface Design of Bintang Hati Novel's Book Cover

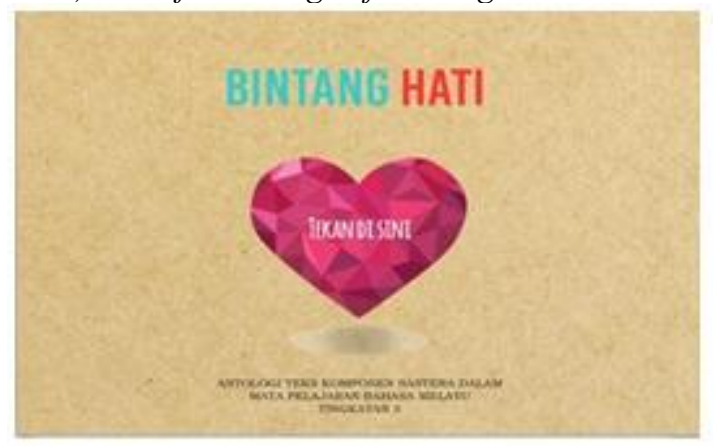

2) Interface Design of Main Menu

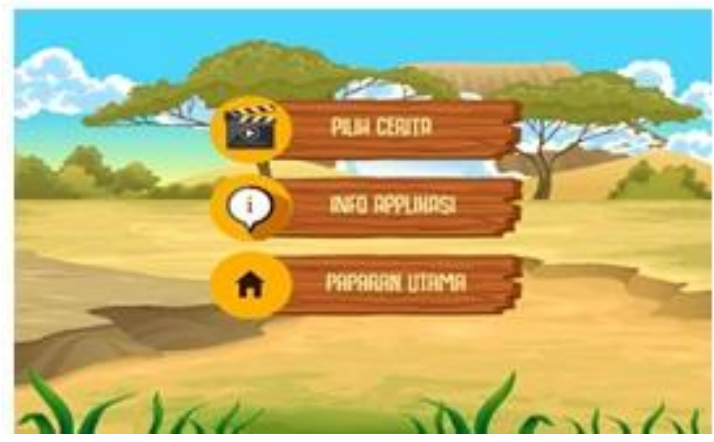

3) Interface Design of Story Selection

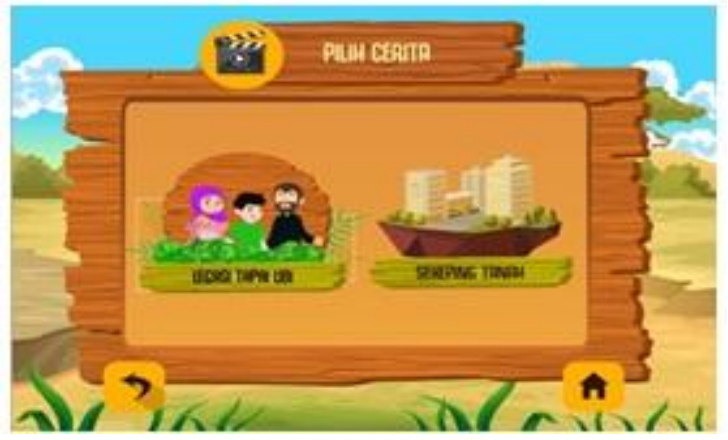

4) Interface Design of Sub Menu

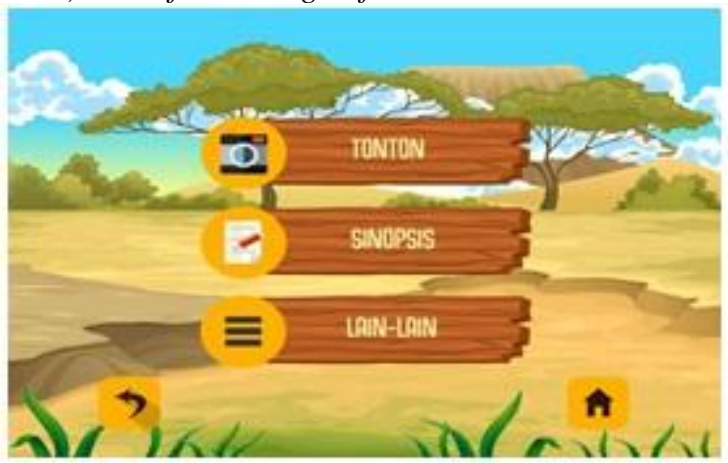

5) Interface Design of Synopsis Story

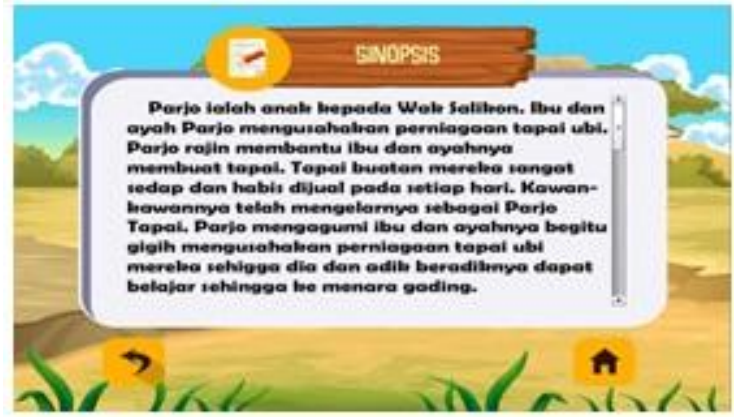

6) Interface Design of Movie Playback

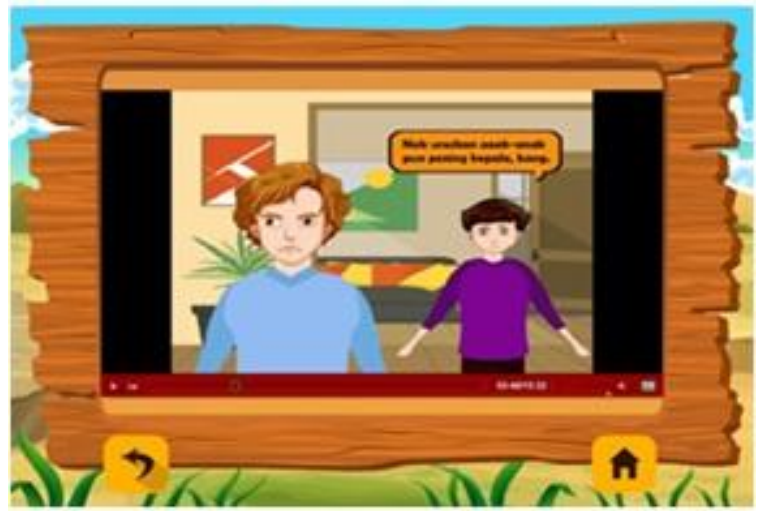

\section{RESULT}

As mentioned above, this study has used various methods in data collection which is referring to the mix method of study. The interview, observation, and questionnaire have been used to strengthen the finding of this study based on the courseware development. The result is measured based on the data collection methods.

\section{A. Observation}

The findings of this study show that interactions and visualization between students and courseware do happened in the classroom when the researcher uses the teaching courseware. However, there can be different level of visualization technique happening concurrently within a classroom. These visualization techniques can be classified as three level of data visualization as follows:

1) Low Level of Data Visualization

This kind of data visualization is categorized as low level because the courseware has no ability to interact with the students when the play button pressed. Most of the time, when the teacher uses the Digital 2D Animation of Bintang Hati courseware for teaching, the students merely watches the computer screen as if watching a movie on television. The students watched the computer screen giving the 'feeling bored and sleepy' face expression and they cannot visualize the content displayed.

2) Moderate Level of Data Visualization

This kind of data visualization is categorized as moderate level when there is an immediate feedback or response upon new things learned during the lesson using the Digital 2D Animation of Bintang Hati application courseware. Responses such as body gesture, facial expression, asking questions, and writing down notes, are the kinds of reactions categorized as moderate level of data visualization. These kinds of visualizations show that students are giving their attention on the content displayed. It indicated that on the knowledge is being shared between the students and what is taught is being digested by the students' minds using the application courseware.

\section{3) High Level of Data Visualization}

High level of data visualization can only happen between the teachers and the courseware. It will happen if the teachers could utilize the courseware as prior to their teaching lesson, and then prepared their own strategies

Published By:

Blue Eyes Intelligence Engineering \& Sciences Publication

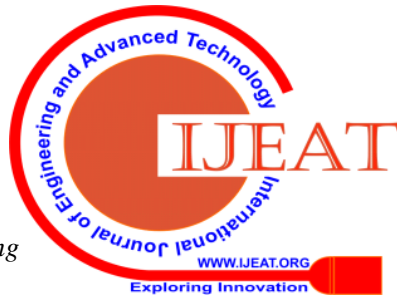


by using their own creativity to visualize the content of the novel. The impact of high level of data visualization can be seen when students use what they have learned from the Digital 2D Animation of Bintang Hati courseware. High level data visualization apply the knowledge when the students are carrying out their own understanding of the story in the novel correctly. This means that students are applying the knowledge in real-time situations. Students' data visualization is highly dependent on the student's response towards the teachers and the courseware in used. Teachers must arrange the questions about the novel's contents to assess the students' understanding, for example by encouraging students to tell and present the story content based on their visualization and understanding in the classroom.

The result of this method shows that all the students were in moderate level of data visualization for the first time they used the application courseware where there has the good feedback from them on the technology integrated in their learning process. The researcher observed their learning process in the classroom and taking notes of their interaction with the application courseware before the data will be organized using Microsoft Excel. Table 4.1 shows the pattern of level of data visualization from the students' feedback.

TABLE 4.1. Pattern of LeVEl of Data Visualization From THe STUDENTS' FEEDBACK

\begin{tabular}{llll}
\hline Feedback & & & \\
Students & Bored & Moderated & Excited \\
\hline S1 & $\sqrt{ }$ & $\sqrt{ }$ & \\
S2 & $\sqrt{ }$ & $\sqrt{ }$ \\
S3 & & $\sqrt{ }$ & $\sqrt{ }$ \\
S4 & & $\sqrt{ }$ & $\sqrt{ }$ \\
S5 & $\sqrt{ }$ & \\
S6 & $\sqrt{ }$ & \\
S7 & $\sqrt{ }$ & $\sqrt{ }$ \\
S8 & $\sqrt{ }$ & \\
S9 & & $\sqrt{ }$ & $\sqrt{ }$ \\
S10 & & $\sqrt{ }$ & \\
S11 & $\sqrt{ }$ & $\sqrt{ }$ \\
S12 & & $\sqrt{ }$ & $\sqrt{ }$ \\
S13 & & $\sqrt{ }$ & $\sqrt{ }$ \\
S14 & & $\sqrt{ }$ & $\sqrt{ }$ \\
U5 & & $\sqrt{ }$ & $\sqrt{ }$ \\
S16 & & $\sqrt{ }$ & $\sqrt{ }$ \\
S17 & & $\sqrt{ }$ & $\sqrt{ }$ \\
S18 & & $\sqrt{ }$ & \\
S19 & & $\sqrt{ }$ & \\
S20 & & & \\
\hline
\end{tabular}

\section{B. Questionnaire}

This method is used to get the user feedback regarding the stories in this application courseware. A set of questions contains the content, user-friendly courseware, and multimedia features is given to the 20 students in order to know their understanding of the storyline using this application courseware compared to reading the printed novel. Besides, to ensure the Digital 2D Animation for Educational Visualization could be the effective way and an alternative learning method for students to understand the storyline faster in a short times period. Figure 4.1 shows the result of the completed user feedback of $95 \%$ from 20 students were answered the questions and got the full score, which is $5 / 5$, and another $5 \%$ of students got $4 / 5$.

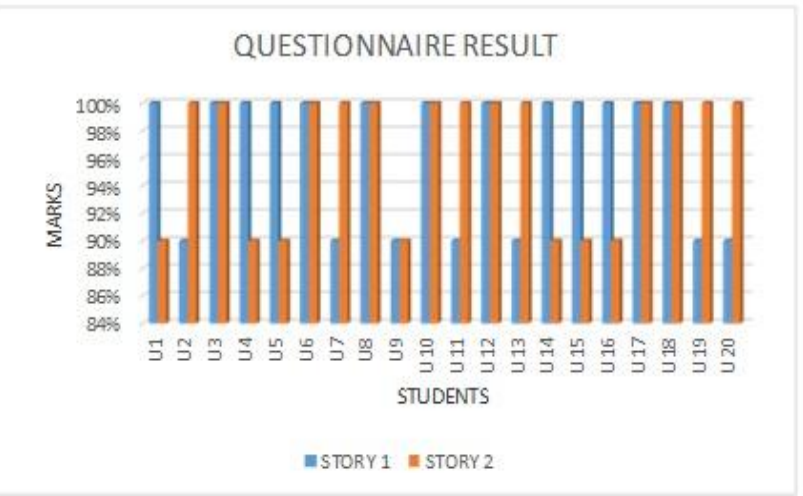

Fig 4.1. Result of Questionnaire

\section{INTERVIEW}

This method is used to get the opinion, comment, or suggestion for the courseware application improvement before it can be used as an alternative method in teaching and learning system in Malaysia's secondary school especially. A set of interview questions has been developed by the researcher which contains of the usability, learnability, memorability, understanding, and motivation. The interview session is conducted on 8 students from 20 students in the classroom which is they were volunteered to be as participants. The researcher was allocated half an hour for each students to be interviewed. The result of the interview is patterned in a form of diagram as shown in Figure 4.2.

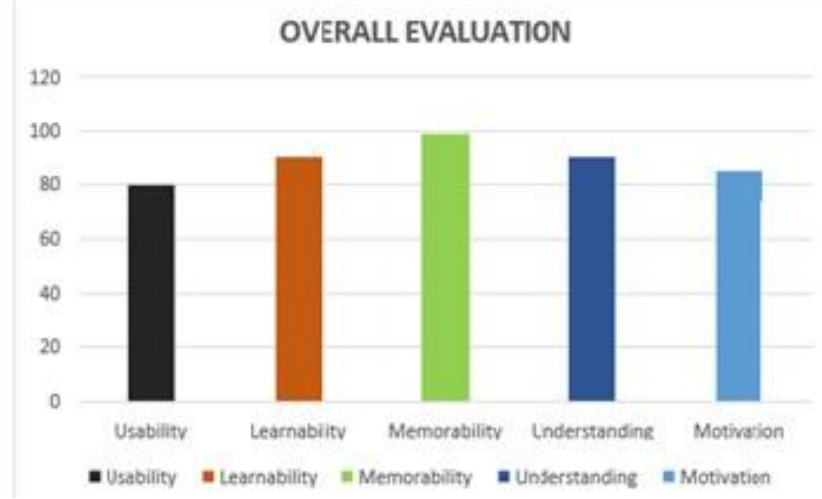

Fig 4.2. Result of Interview for Overall Application Courseware

\section{Conclusion}

This study provided a review for studies showing the role of animation in special education. The results primarily revealed that based on the increasing use of technology in special education, animations have gained great attention recently and its found to be an 
effective instructional tool for enhancing learning process of individuals with the special needs. In the present era, it is recommended for teachers and other professionals in educational system to follow the trends of innovational technology and use tools of information technologies in education effectively during teaching processes and lecture presentations. The use of animation as one of the effective tools of Information Technology in education has tremendously increased in recent time. Therefore, it is highly recommended that the use of animation in enhancing learning of individuals with special needs, and in addition to individuals with typical development is encouraged.

This application courseware is well developed and had met the target user's requirements. All the methods and techniques in developing this application courseware are successfully functioned. The objectives of this application is successfully achieved. The overall evaluation, functional testing and user feedback are successfully conducted to the user and the result shows that Digital 2D Animation for Educational Visualization Application is well functioning and successfully assisted the PT3 students as participants in this study to visualize the content of two stories of Bintang Hati novel and it is still having to be improved and upgraded for future work.

\section{A. Implications of the Study}

The findings from the analysis have respond to the study's research questions and help to achieve its goals, which are to transform the traditional learning method into the digital learning which is with the technology assisting enable students learning in fast and interesting. Besides that, using digital 2D animation in deliver content from printed book into visualization will make student more understand the story line and help them to imagine the real situation of the story. It is also can make students memorize the story in a long time period compared to reading book only. Therefore, at this age, technology in learning is a necessity not just an option because of the growing technology.

\section{ACKNOWLEDGMents}

The authors would like to thank all those who cooperated in the conduction of this study.

\section{REFERENCES}

[1] Sun, J.Y., Guo, T.Y., 2012. Inquiry and Practice of the Reform of 2D Animation Making Course. Journal of Changchun Finance College, 2012, vol. 15(1), pp. 68-71.

[2] Hsieh P. H., 2017. Senior High School Students' Comprehension and Interest in Science Content: Example of Participating in First-Hand Experimental Activities. Journal of Science and Technology, Vol. 9 No. 1, p. 7-14.

[3] Schank, R. C., 1995. Tell Me A Story: Narrative and Intelligence. Evanston, Illinois: Northwestern University Press.

[4] Norhayati Abd. Mukhti, H. B. Z., Tengku Mohd Tengku Sembok, Siew Pei Hwa, \& Zurina Muda., 2000. A Pedagogical Approach to Multimedia Courseware Development to Motivate Reading Habit. TENCON Proceedings, Intelligent Systems and Technologies for the New Millennium (Cat. No.00CH37119), 1, 134-139. DOI:10.1109/TENCON.2000.893557

[5] Mixon, M. \& Temu, P., 2006. First Road to Learning: Language through Stories. English Teaching Forum, Issue. 3, November: 14-19.

[6] Cooter, R., 1991. Storytelling in The Language Arts Classroom, Reading Research and Instruction. 30(2): 71-76.

[7] Mallan, K., 1996. Storytelling in rural areas (SARA): Making Links Between Home and School. Australian Journal of Early Childhood. 21(1): $1-5$

[8] Raines, S. \& Isbell, R., 1994. Stories: Children's Literature in Early Education. Albany, NY: Delmar.

[9] Isbell, R. T., 2002. Telling and Retelling Stories: Learning Language and Literacy. Young Children (March, 26-30), Retrieved on 21st July 2014. www.naeyc.org/ycn.

[10] Elaf, S. A., 2012. The Effect of Storytelling on Vocabulary Acquisition, University of Tikrit College of Education for Women/English http://www.iasj.net/iasj?func=fulltext\&aId=39919.pdf

[11] AiniArifah \& Norizan., 2008. Using Teaching Courseware to Enhance Classroom Interaction as A Method of Knowledge Sharing. Journal of Information Systems, Research \& Practices, Vol.1(1).

[12] Basak, Yucehan \& Ahmet., 2018. Using Animation as a Means of Enhancing Learning of Individuals with Special Needs. TEM Journal. Volume 7, Issue 3. Pages 670-677.

[13] Toroglu, A. \& Icingur, Y., 2007. Uc Boyutlu Bir Animasyon Sisteminin Tasarimi Ve Teknoloji Egitiminde Kullanılmasi. Politeknik Dergisi, 10(3), 247-252.

[14] Osborne, J. \& Hennessy, S. (2003). Literature Review in Science Education and the Role of ICT: Promise, Problems and Future Directions. Futurelab Series, Report 6.

[15] Mork, S.M., 2005. Argumentation in Science Lessons: Focusing On the Teacher Role. Nordic Studies in Science Education, 1 (1). 16-29.

[16] Chisholm, I. M., 1995. Computer Use in A Multicultural Classroom. Journal of Research on Computing in Education, Winter 1995/96, 28 (2). 162-178.

[17] Ahmad A. M., Mu'azah M. A., Mahani W., Izril M., 2018. Kid's Education and Fun Courseware. International Journal of Engineering \& Technology, 7 (4.28).

[18] Anderson: Wikipedia, the free encyclopedia (2010) http://en.wikipedia.org/wiki/Animation (retrieved August 31, 2010)

[19] Cipolla-Ficarra, F.V., Cipolla-Ficarra, M., 2009. Computer Animation and Communicability in Multimedia System: A Trichotomy Evaluation. In: Damiani, E., Jeong, J., Howlett, R.J., Jain, L.C. (eds.) New Directions in Intelligent Interactive Multimedia Systems and Services - 2. SCI, vol. 226, pp. 103-115. Springer, Heidelberg.

[20] Papanikolaou, K.A., Grigoriadou, M., 2005. Modelling and externalising learners' interaction behaviour. In: Proceedings of Workshop on Learner Modelling for Reflection, International Conference on Artificial Intelligence in Education, Amsterdam, Netherlands, pp. 52-61.

[21] Richards, D., Kelaiah, I., 2012. Usability Attributes in Virtual Learning Environment. In: IE 2012, Proceedings of the 8th Australasian Conference on Interactive Entertainment: Playing the System, Auckland, New Zealand, July 21-22.

[22] Peterson, C., 2003. Bringing ADDIE to Life: Instructional Design at Its Best. Journal of Educational Multimedia and Hypermedia, 12(3), 227-241.

[23] Friedman A. \& Schneider E., 2018. Developing a Visualization Education Curriculum in the Age of Big Data Using the Dick and Carey Model. Pages 250-256. Published online: 20 Dec 2018. https://doi.org/10.1080/15551393.2018.1530115

[24] Stokes S., 2002. Visual Literacy in Teaching and Learning: A Literature Perspective. Electronic Journal for the Integration of Technology in Education, vol. 1, no. 1.

[25] Domik G., 2000. Do we need formal education in visualization? IEEE Computer Graphics and Applications 20(4):16 - 19. August 2000. DOI: $10.1109 / 38.851744$.

[26] Gelman \& Unwin., 2013. Infovis and Statistical Graphics: Different Goals, Different Looks. Journal of Computational and Graphical Statistics 22(1) · DOI: 10.1080/10618600.2012.761137

[27] Snee., 2003. Visualizing Independence Using Extended Association Plots. Proceedings of The 3rd International Workshop on Distributed Statistical Computing (DSC 2003).

[28] M. Sicilia, S. Ruiz, J.L. Munuera., 2005. Effects of Interactivity in A Web Site: The Moderating Effect of Need for Cognition, J. Advert. 34, 2005, pp. 31-44

[29] G. van Noort, H.A.M. Voorveld, E.A. van Reijmersdal., 2012 Interactivity in Brand Websites: Cognitive, Affective, And Behavioral Responses Explained by Consumers' Online Flow Experience, J. Interact. Mark. 26, 2012, pp. 223-234. 